\title{
The Camel and the Wheel
}

Richard W. Bulliet

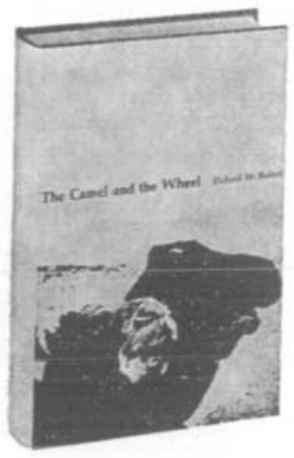

A fascinating, richly illustrated analysis of the substitution of the pack camel for the wheeled vehicle in the last 17 to 14 centuries in the Middle East and North Africa. The author draws on anthropological, linguistic, and archaeological evidence in demonstrating the enormous economic and social importance of the camel. $\$ \$ 16.00$

\section{A Sufi Rule for Novices}

MENAHEM MILSON, Translator

\section{Harvard}

Rather than expounding the mystical doctrines of Islamic, this pop: ular twelfth-century text is a guide to proper etiquette, offering general rules for such social proprieties as eating, clothing, marriage, and hospitality. Addressed both to laymen and to beginners on the Sufi path, this extraordinary manual will be a welcome addition to the already influential writings on Sufism which are enjoying tremendous popularity in this country today.

July, \$8.95

$122 p p$. 
(In Its Fourth Year of Publication:)

Journal of.
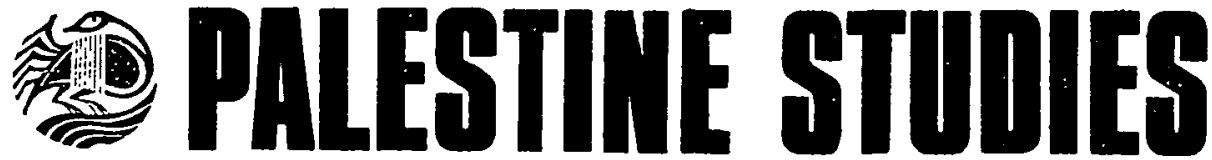

A Quarterly on Palestinian Affairs and the Arab-Israeli Conflict

This English-language quarterly deals exclusively with the Palestine problem and the Arab-Israeli conflict. Analytical articles by MiddleEast specialists and public figures, book reviews, an exhaustive bibliography, extracts from the Hebrew and Arab press, as well as documents and source material (normally inaccessible to the English-language reader), all make each issue of the Journal an intelligent, comprehensive and thorough round-up of the development of the conflict during each quarter.

Contributors in past issues (in interview or article form) have included:

JEAN GENET, ARNOLD TOYNBEE, MOHAMMED HASSANEIN HEYKAL, JEAN LACOUTURE, IGOR BELYAEV, DAVID HIRST, GEORGE TOMEH and ALAN TAYLOR.

Annual subscription rates:

$\begin{array}{lll}\text { One year: } & \text { US } \$ 12.00, & 4.90 \text { Pounds Sterling } \\ \text { Student rate: } & \text { US } \$ 7.00, & 2.80 \text { Pounds Sterling } \\ \text { Single copy: } & \text { US } \$ 3.00, & 1.20 \text { Pounds Sterling }\end{array}$

Obtainable from:

INSTITUTE FOR PALESTINE STUDIES P.O: Box 11-7164 Beirut, Lebanon

I.P.S. (Distribution)

Box 329, R.D. 1

Oxford, Pa. 19363,

U.S.A.
A.S.P. Distributors

7 Bishopsthorpe Road

London SE26 4NZ

England 


\section{PAHLAVI UNIVERSITY DEPARTMENT OF HISTORY SHIRAZ, IRAN}

Applications are invited for position at Assistant/Associate professor level. Duties include research and teaching at the undergraduate level.

Ph.D. in Near Eastern History, with specialities in islamic History, Archaeology and Ancient Iranian History, and Modern Iranian History.

Appointment on a two-year renewable contract with an annual salary range equivalent to $\$ 12,000$ to $\$ 16,000$ depending on qualifications and experience.

Please send written application, curriculum vitae and confidential recommendation from three referees to Department of History, Pahlavi University, Shiraz, Iran. 


\section{ENGLISH TRANSLITERATION SYSTEM \\ CONSONANTS}

Column Headings: $\mathrm{A}=$ Arabic, $\mathrm{P}=$ Persian, $\mathrm{OT}=$ Ottoman Turkish, $\mathrm{MT}=$ Modern Turkish

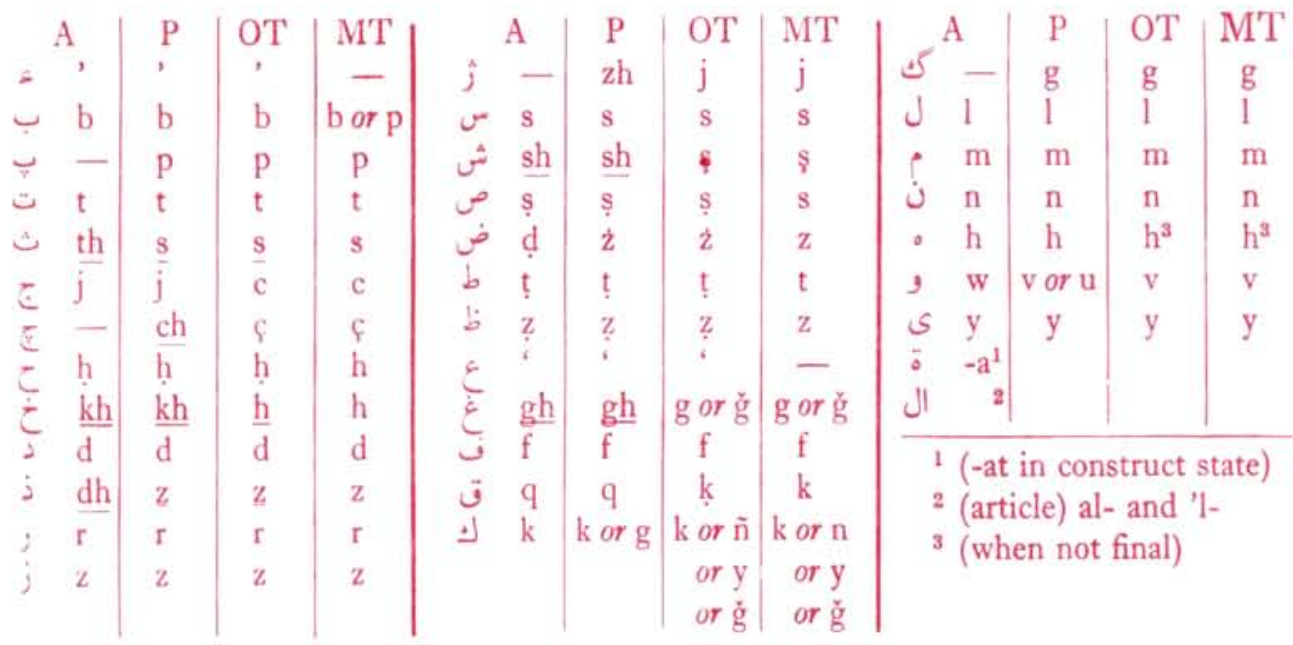

\section{VOWELS}

ARABIC AND PERSIAN

$$
\begin{array}{rr}
\text { Long I or 's } & \text { â } \\
g & \text { û } \\
\text { s } & \hat{i}
\end{array}
$$
Doubled $\because \begin{gathered}\text { iyy (final } \\ \text { form î) }\end{gathered}$

9 uww (final form û), etc.
OTTOMAN TURKISH

\section{MODERN TURKISH}

$\hat{\mathrm{a}}\left\{\begin{array}{c}\text { words of Arabic } \\ \text { and Persian } \\ \text { origin only }\end{array}\right\}$

iy (final

form î)

uvv

Shor

$$
\mathrm{S}^{-} \text {au or aw }
$$

$$
\begin{aligned}
& \text {, } u \\
& =\sim i
\end{aligned}
$$

ev

ey

a or e

$\mathrm{u}$ or $\mathrm{u}$

o or ö

1 or i uvv

ev

ey

iy (final form i)

a or $\mathrm{e}$

$\mathrm{u}$ or i

o or ö

1 or i

For Ottoman Turkish, authors may either transliterate or use the modern Turkish orthography. Articles submitted in French and German may be transliterated according to the systems common in those languages. 


\section{CONTENTS}

THE EdTOR'S DESK

Peter von Sivers Insurrection and Accommodation: Indigenous

Leadership in Eastern Algeria, $1840-1900$

Kemal H. Karpat The Memoirs of N. Batzaria: The Young Turks and Nationalism

pages $257^{-25} 8$

William L. Ochsenwald Ottoman Subsidies to the Hijaz, 1877-1886

YA'AKov Firestone Production and Trade in an Islamic Context:

Sharika Contracts in the Transitional Economy of Northern Samaria,

I $853^{-1} 943$ (II)

Alan S. Kaye Review Article: More on Diglossia in Arabic

$259^{-275}$

276-299

300-307

BOOK REVIEWS

c. Cambridge University Press, 1975

\section{The Middle East Studies Association of North America, Inc.}

This association was founded in 1966 in order to promote high standards of scholarship in the field of Middle Eastern studies and to facilitate communication among scholars through meetings and publications. In addition to sponsoring the fournal, which is published for the Association by the Cambridge University Press, MESA publishes a Bulletin periodically, holds an Annual Conference, and provides other professional services for its members from time to time. Enquiries concerning membership, which includes subscription to the International fournal of Middle East Studies, should be addressed to: Headquarters and Secretariat, Middle East Studies Association, New York University, Washington Square, New York, N.Y. $1000_{3}$, U.S.A. Fees are as follows: Fellows and associates, $\$_{30.00}$; students, $\$_{12.50}$; institutions, $\$_{40.00}$.

\section{Notes for Contributors}

Contributions and editorial correspondence should be sent to the Editor, Professor Stanford J. Shaw, The Gustave E. von Grunebaum Center for Near Eastern Studies, University of California, Los Angeles, California, 90024, U.S.A. Submission of an article implies that it has not been published or is not being considered for publication elsewhere. In the interests of authors, copyright is normally assigned to the Cambridge University Press. Articles in English should conform with the Journal's transliteration system. Articles will be accepted and published in French and German, with the authors expected to follow the transliteration systems normally used in those languages. Care will be taken with manuscripts submitted, but the Editor cannot accept responsibility for any loss or damage which may take place. Short summaries should be included with every manuscript. Contributors should keep at least one copy for use in correcting proofs. Contributors of articles and review articles receive 50 offprints. Extra copies may be purchased according to an agreed scale of charges.

\section{CAMBRIDGE UNIVERSITY PRESS}

Bentley House, 200 Euston Road, London NWI 2DB

32 East $57^{\text {th }}$ Street, New York, N.Y.10022

Price $£_{4.00}$ (US $\left.\$ 10.00\right) 1975$ subscription price $£_{12.00}$

(US $\$ 28.50$ in U.S.A. and Canada)

Printed in Great Britain at the University Printing House, Cambridge 